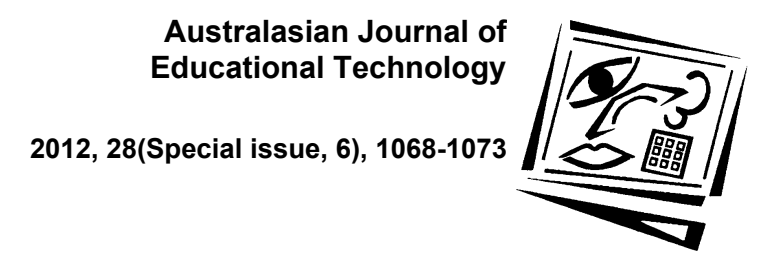

\title{
Introduction of ICT and multimedia into Cambodia's teacher training centres
}

\author{
David Dionys \\ VVOB (Flemish Association for Development Cooperation and Technical Assistance) \\ Cambodia
}

\begin{abstract}
This article describes the integration of ICT in the teacher training centres of Cambodia. It focuses on the collaboration between the Teacher Training Department of the Ministry of Education, Youth and Sports (MoEYS) of Cambodia and VVOB (Flemish Association for Development Cooperation and Technical Assistance), which is aimed at improving ICT integration in pre-service teacher training. The article firstly provides an overview that outlines the major challenges the country is facing regarding ICT integration in education, and teacher training specifically. Then it will explain the strategy chosen to improve the quality of education, followed by a discussion of the concrete actions that were taken. While the integration is an ongoing process, some intermediate impacts and findings are discussed. This short paper concludes with a look at the challenges lying ahead.
\end{abstract}

\section{Challenges for ICT integration in Cambodia's teacher training}

Cambodia's education system has come a long way since recovering from the devastating effects of the nation's recent past. In the Khmer Rouge period, educational institutions were abandoned, books were destroyed and teachers and intellectuals either died or fled to other countries. After the fall of the Khmer Rouge regime in 1979, chaos and violence delayed substantial improvements in education. It was only after the signing of the peace agreements in Paris in October 1991 that functioning of public systems was truly revised; progress since then has been considerable, although there remain obstacles that need to be overcome in order to provide Cambodia's children with a quality education.

The first problem is the overall teaching quality. Teaching content is relatively limited. While textbooks have been updated in recent years, there are still few teaching support materials and digital learning materials available. Teaching and academic staff have not received enough training. Although basic computer skills training has been provided for teacher trainers from 2003 onwards, there were few opportunities for teachers to practice due to the inadequate supply of computer facilities (there were on average only 2 computers for 15 teacher trainers per college). This has left many teachers' digital literacy only at beginners' level. In addition, fear of using ICT remains a considerable obstacle in Cambodia. Pedagogical use of ICT integration is only starting to emerge due to recent efforts.

Secondly, infrastructure remains weak. Electric power supply is often unstable, which results in frequent power blackouts, and electrical sockets are often not present in classrooms. Few teacher training centres have acceptable computer labs. A recent 
VVOB survey found that only six out of 18 Provincial Teacher Training Centres (primary education) had enough computers for teaching ICT competencies to student teachers. The situation is better in the six Regional Teacher Training Centres (lower secondary education) which usually are equipped with computer labs. On the other hand, many computers become obsolete quickly, and sustainability is problematic when little budget is present to replace or update the old computers. In addition, Internet connectivity is absent in many colleges, and the current connection is very slow and thus inconvenient (one $128 \mathrm{~kb} / \mathrm{s}$ line in most cases).

Lastly, there are also concerns about college management. There is little understanding of the integration of ICT in the colleges. It seems the institutional capacity for management of ICT in the educational context is far from enough.

For these reasons, the use of computers in classroom settings has been very limited in Cambodia.

\section{Strategy and guiding principles}

VVOB and MoEYS have started implementing the SEAL (Science, Environmental and Agricultural Life skills) program since 2008. This program focuses on the improvement of quality of teacher training in the areas of sciences and environmental and agricultural life skills. ICT is used to support student-centred teaching methodologies by stimulating the use of digital learning materials in teacher training. A demanddriven approach was followed, aligning with the existing MoEYS ICT in education master plan and teacher development plan (MoEYS, 2010).

The guiding principle of the SEAL program is the TPACK model (Mishra \& Koehler, 2006). VVOB seeks to increase the teacher trainers' understanding on how to integrate technological, pedagogical and content knowledge in teaching practice. ICT in this context is considered as a tool to enhance capacity development. Taking into account the three main problem areas identified (teaching quality, infrastructure and institutional capacity), the aims for the ICT part of the program are threefold.

The highest priority is the provision of high quality digital learning materials and the corresponding training. Confidence, time and access to quality digital resources are major factors that determine teachers' engagement with ICT in a classroom setting (BECTA, 2004). Quality digital resources are those providing added value to teacher training. For science teaching, the use of interactive simulations contributes significantly to a better conceptual understanding (National Research Council, 2011). Early rigorous research studies (CISCO, 2006) demonstrated the positive impact of video and multimedia on student learning outcomes; these were hence the formats used in the SEAL program.

An important principle was to select the materials starting from the current curriculum, thus ensuring suitability. As the added value of multimedia is highest when no real life objects can be used to demonstrate the topic, there was a special focus on abstract topics. Support materials are also considered to be quintessential. As described by Linn, Chang, Chiu, Zhang and McElhaney (2010), simulations should be presented in a meaningful scientific context and supportive instructions on how to conduct simulated experiments should be provided. 
It makes little sense to promote use of digital resources for teaching without ensuring minimum conditions with respect to equipment and management. The program therefore provided a limited set of equipment to each of the teacher training centres. End users were trained in technical use of the equipment. Special attention was also given to include staff at management level to stimulate and promote the use of the digital resources in teaching practice.

\section{Actions taken to enhance teacher trainers' ICT competencies}

\section{Provision of digital learning materials and training to enhance teaching quality}

Considering the nature of interactive multimedia development and constraints on budget and human resources, VVOB opted to localise existing open educational resources. Over 200 interactive multimedia applications for science were selected, translated to Khmer and otherwise localised. For example, 200 science experiment video clips were produced, explaining the setup, theoretical understanding and pedagogical use of low cost science experiments. For life skills, over 100 video clips were selected from existing resources, and over 30 model lessons were filmed. All materials have been submitted to quality control by stakeholders.

Support materials were made available in the form of manuals and activity sheets. Activity sheets for interactive multimedia contain references to the curriculum, information on target audience and duration, which establish clear learning objectives and student outcomes in terms of students' knowledge, skills and attitude. Furthermore, they contain an extensive description of examples on how to use the interactive multimedia applications, linked to the Cambodian lesson plan format and providing possible integration of student centred approaches into the lesson.

Both digital and printed materials are made available in an off-line version (as a box set including DVDs) and online through the clearing house website http:/ / www.krou.org/ ("krou" meaning teacher in the Khmer language). The website will be upgraded thoroughly by the end of March 2012 through the improvement of user experience and an extended availability of learning materials. Users can download materials freely from the website and are encouraged to upload their own contributions.

Teacher trainers received training in a series of workshops taking place from September 2011 onwards. During these workshops, the focus lay on the pedagogical use of multimedia which aims at stimulating higher order thinking skills. The main challenge is the integration with student centred approaches (teacher trainers have traditionally worked from a rote learning perspective). During the workshops, teacher trainers explore the available materials, and they then use the materials in their own classroom context.

\section{Equipment and infrastructure}

The infrastructure problem was tackled by providing some ICT equipment to the colleges. Initially, desktop computers were installed in a resource room for teacher trainers, together with equipment for use in the classroom (DVD player, TV, projector, netbook, etc.). The total amount of equipment was kept minimal in order to avoid sustainability and maintenance problems. In addition, previous experiences have illustrated that donating a large number of computers does not contribute to more 
effective teaching. After all, the objective behind providing enough equipment was to enable and stimulate effective use of the multimedia in the classroom by teacher trainers.

Within our working context, digital literacy had to be supported up to a certain extent. Instead of providing standard basic ICT skills training, which mainly targets instruction in office software, a training program that modified and extended the Intel Teach program was used to provide ICT training focused (exclusively) on skills that teacher trainers will need in an educational context.

\section{Institutional capacity building}

In order to enhance the involvement and ownership of the Ministry, the central teacher training department was systematically involved. Communication was enhanced through intensive collaboration, including meetings, survey taking, fact finding missions and lesson observations. Management of equipment (responsibility for borrowing and safety, maintenance, stimulation of use, location to install the equipment) was evaluated within the local context of each teacher training centre. Strategies to stimulate use of ICT in the classroom were discussed, and in the training workshops time was taken for the colleges to share good practices. Evaluation of the use in teacher training was also taken into account; evaluation formats for lesson plan preparation and lesson observations will be constantly refined, and the actual use of the resources is tracked through logbooks. A special training for ICT focal point persons in the colleges was scheduled in May 2012.

\section{Impact and findings}

\section{Lessons learned for enhancing teaching quality}

The digital learning materials produced have been made available and were received well both by management and teaching staff. Teacher trainers consider students have improved their conceptual understanding of the topics taught, so the use of digital materials has been found to be stimulating and motivating. Given the existing general lack of teaching materials, their publication is a major step forward towards the effective integration of ICT in teacher training practice.

Activity sheets initially had a more condensed format, which seemed very challenging for teacher trainers to use. In order to diminish their fear of using the innovative materials, the support materials were made more explicit, describing each step in detail (including the configuration of simulations, sample questions, and relevant learning outcomes). It is believed this can help reduce their resistance to the use of digital materials.

There is a considerable strain on human resources. Although the level of donor coordination and harmonisation is high, the absorptive capacity of teacher training staff is limited. In order to keep all participants in the loop, it is essential that the same participants attend the mainstreaming workshops.

\section{Lessons learned for equipment}

The use of the resource rooms is less than expected. There are various factors leading to this situation. In the first place, teacher trainers do not remain in their college in 
between or after lessons. Also, some colleges reported having difficult administrative procedures for borrowing the equipment. Finally, the fear of technology is still present amongst the teacher trainers, which is partly due to the average age of the involved teacher trainers. Although they are no digital natives, hopeful signs appear that indicate an increased digital literacy. In the future, we will focus on the promotion of the use of laptops and projectors in the classroom, as this leads to core integration in teaching, and stimulates the management to take action to make use of equipment easier.

It is remarkable that teacher trainers still consider technology skills as the major barrier for integrating ICT, while this aspect has received ample attention. Skills needed to use interactive materials are few, like successfully connecting projectors and navigating the interactive multimedia. However, further exploration and practice with multimedia in the classroom should overcome this resistance to using technology.

\section{Lessons learned for institutional capacity development}

Teacher trainers mentioned that ongoing follow-up and monitoring is crucial to the success of the program. Lesson observations and monitoring of the use of ICT equipment are considered the ultimate assessment for the program's outcome. It is hoped that the increased use of monitoring tools (logbooks, etc) will lead to a better understanding of bottlenecks, an enforcement of ICT management and an identification of the champions of ICT use.

Likewise, within the teacher training centres it is considered that the presence of a focal point person at management level will make a big difference. Due to the recent introduction of ICT in the colleges, these leadership structures are only now emerging, which reveals a lack of coordination for ICT activities. Good leadership and sharing of good practices are likely to have a direct impact on ICT use. The focal point person would furthermore serve as the central responsibility point for taking care of emerging problems.

\section{Conclusion: Challenges for the future}

While progress has been made, the successful integration of ICT is still some way off. The biggest challenge ahead is that of an attitude change, especially regarding didactics and student centred approaches. Teacher trainers often implement these techniques in a correct format, but without effectively having the students engaged. The further distribution of materials together with focused training is likely to enhance their effective use. Technical training will be continued, and equipment and technical skills should no longer be the main bottlenecks in the near future. The successful functioning of ICT focal point persons will provide for local leadership that increases the use of digital materials in the classrooms.

\section{References}

BECTA (2004). A review of the research literature on barriers to uptake of ICT by teachers. http:/ / dera.ioe.ac.uk/1603/1/becta_2004_barrierstouptake_litrev.pdf

CISCO Systems and Metiri Group (2006). Technology in schools: What the research says. http:/ / www.cisco.com/web/strategy/docs/education/TechnologyinSchoolsReport.pdf 
Linn, M. C., Chang, H. Y., Chiu, J., Zhang, H. \& McElhaney, K. (2010). Can desirable difficulties overcome deception clarity in scientific visualizations? In A. S. Benjamin (Ed.), Successful remembering and successful forgetting: A Festschrift in honor of Robert A Bjork (pp. 239-262). New York: Routledge.

Mishra, P. \& Koehler, M. J. (2006). Technological pedagogical content knowledge: A framework for teacher knowledge. Teachers College Record, 108(6), 1017-1054. http: / / www.tcrecord.org/ Content.asp?ContentID=12516

MoEYS (2010). Master plan for information and communication technology in education 2009-2013. http: / / www.moeys.gov.kh/en/ component/joomdoc/doc_download/39-master-plan-foricten.html

National Research Council. (2011). Learning with simulations and games. In M. A. Honey \& M. L. Hilton (Eds.), Learning science through computer games and simulations (pp. 25-55). Washington, DC: The National Academies Press.

http: / / www.nap.edu / catalog.php?record_id=13078

Author: David Dionys

Flemish Association for Development Cooperation and Technical Assistance (VVOB),

Cambodia

Email: david.dionys@vvobcambodia.org Web: http:/ / www.vvob.be/ cambodia/

Please cite as: Dionys, D. (2012). Introduction of ICT and multimedia into Cambodia's teacher training centres. In C. P. Lim \& C. S. Chai (Eds), Building the ICT capacity of the next generation of teachers in Asia. Australasian Journal of Educational Technology, 28(Special issue, 6), 1068-1073. http: / / www.ascilite.org.au/ajet/ajet28/dionys.html 